Discussion Paper No. 921

\title{
RELATIVE INCOME POSITION AND HAPPINESS: \\ ARE CABINET SUPPORTERS DIFFERENT FROM OTHERS IN JAPAN?
}

\author{
Eiji Yamamura \\ Yoshiro Tsutsui \\ Fumio Ohtake
}

January 2015

The Institute of Social and Economic Research

Osaka University

6-1 Mihogaoka, Ibaraki, Osaka 567-0047, Japan 


\title{
Relative income position and happiness: are cabinet supporters different from others in
} Japan?

\author{
Eiji Yamamura (Seinan Gakuin University) \\ Yoshiro Tsutsui (Konan University). \\ Fumio Ohtake (Osaka University)
}

\begin{abstract}
During the period of 2001-2006, the Liberal Democratic Party (LDP) adopted a market-oriented policy under the Koizumi cabinet. In 2006, following the formation of the first Abe cabinet, the LDP returned to a traditional redistributive policy. We assume that the supporters of the Koizumi cabinet had an expectation of upward income mobility via the market. On this assumption, using data covering the Koizumi and first Abe cabinets, this paper attempts to examine whether the effects of relative income differ between supporters and non-supporters of the Koizumi cabinet. Key findings are as follows: within the Koizumi cabinet period, a relatively low-income position is negatively related to happiness for non-LDP supporters but not for LDP supporters. However, under the period of the first Abe cabinet, the difference in the effect of relative income for LDP supporters and others disappears. These results imply that an expectation of market outcomes leads to a difference in the effect of relative income position on happiness levels. Namely, during the Koizumi cabinet period, low-income supporters believed that their income position would improve under Koizumi's market-oriented policy, and during the Abe cabinet period, low-income LDP supporters, like non-supporters, did not hold such an optimistic view.
\end{abstract}

Keywords: Relative income, Positional concerns, Happiness, Government supporter, Japan.

JEL Classification: I31, D72 


\section{Introduction}

It can be argued that the orientation of government policy is associated with an individual's overall evaluation of quality of life or subjective well-being (SWB). The subjective evaluation of an economic situation can vary according to social and political conditions. Alesina et al. (2004) found that in the United States, inequality decreased high-income earners' levels of happiness but not that of low-income earners. Previous studies have shown that happiness levels are influenced not only by one's own income but also by the income level of peers such as neighbors (e.g., Clark and Oswald, 1996; Luttmer, 2005). Individuals' happiness levels seem to depend on whether their income is higher or lower than the reference group. It is widely acknowledged that relative income in society exerts an effect on an individual's happiness level (Clark et al., 2008). However, there has been little research to date on whether the effect of relative income differs according to individuals' views of the market.

The Liberal Democratic Party (LDP) is Japan's most consistently successful political party. The LDP is regarded as a politically conservative party, distinctly different from Japan's opposition parties, which are considered progressive parties ${ }^{1}$. In addition to its political principles, the LDP's economic policies have traditionally placed a high level of importance on income redistribution, a reallocation from the urban to rural areas. In the past the LDP received strong support from interest groups rooted in rural areas (Doi and Ihori, 2009). In contrast, other parties such as the Socialist Party largely promote labor rights and so aim to improve labor conditions. Despite the obvious differences in policy among political parties, the LDP's economic policy was similar to that of other parties in that the market mechanism was given very little consideration. However, a market-oriented policy was later adopted under the Koizumi cabinet, and Koizumi received great support from urban residents (a change from that from rural residents). Shinzo Abe, whose first term as Prime Minister succeeded Koizumi's, weakened the market-oriented policy and returned to traditional LDP economic policy.

The effect of relative income on SWB has been examined previously using Japanese data (Oshio et al., 2014). Investigations have also explored whether political preference and political events are related to SWB in Japan (e.g., Tsutusi et al., 2010, Kinari et al., 2014, Tsutsui et al., $2014)^{2}$. However, existing studies have not investigated whether a change of orientation of economic policy influences the effect of relative income on SWB. There is the possibility that

\footnotetext{
${ }^{1}$ Today, even in non-government parties, more members now hold conservative views. Consequently, the progressive differences between the LDP and non-government parties are disappearing.

${ }^{2}$ Social capital is related to SWB in Japan (Kuroki, 2011, Yamamura et al., 2014).
} 
the effect of relative income position is asymmetric for "poorer" people and "richer" people (Ferrer-i-Carbonell, 2005) ${ }^{3}$. Ferrer-i-Carbonell (2005) used German data to show that the effect of relative income on SWB is asymmetric for West Germans and symmetric for Eastern Germans. The case of Germany suggests that the historical background of political and economic conditions is related to whether the effect of relative income is asymmetric. It is worthwhile to explore whether such an asymmetric effect possibly depends on the orientation of a country's economic policy. This examination is anticipated to suggest how an individual's expectation about the outcome of economic policy is related to SWB.

Looking at the Koizumi cabinet period, we can compare the influence of relative income between LDP supporters and others, and this enables us to examine how and the extent to which the effect of relative income on SWB varied under the different orientation of Japan's economic policy. The estimation of this paper is based on individual data from August 2005 to January 2007, covering the Koizumi and the first Abe cabinets. Using regression estimations we obtained the following results. A relatively high-income position is positively related to happiness; this result does not change using different samples. In contrast, during the Koizumi cabinet period, a relatively low-income position is negatively related to the happiness levels of non-LDP supporters but not of LDP supporters. During the Abe cabinet period, a relatively low income is negatively related to the happiness of non-LDP supporters and LDP supporters. Hence, the different effect of relative income between LDP supporters and non-LDP supporters disappeared because of a change of orientation of economic policy.

We structure our paper as follows: we outline the meaning of the statistical estimation changes according to political context in Japan. It is necessary to understand the political background in Japan; thus, for this purpose, Section 2 provides an overview of the political situation in Japan. Section 3 explains the data used in this paper, proposes the testable hypotheses, and presents the methodology. Section 4 reports the estimation results. Section 5 provides the conclusion of this paper.

\section{Political Situation in Japan}

Since coming to power in 1955, the LDP has been Japan's dominant party ${ }^{4}$. The LDP is a major conservative party with economic policies that have sought to ensure redistribution of

\footnotetext{
${ }^{3}$ Existing research shows that the influence of income comparisons is asymmetric (e.g., Duesenberry, 1949; Hollander, 2001; Frank, 1985).

4 The LDP has been in power since 1955, except for two short periods in 1993-1994 and 2009-2012.
} 
wealth from urban to rural areas 5 . In contrast, the principal policy of Junichiro Koizumi relied upon market mechanisms to increase economic efficiency. During this time, the Koizumi cabinet was regarded as heretical by LDP members towing the traditional LDP line. However, Koizumi cleverly attracted media attention and gained the support of the majority of voters throughout Japan (Yamamura and Sabatini, 2014). "Koizumi came to power via a revolt by the LDP's grassroots urban machine against the more rural-oriented party leadership" (Katz 2001, p. 38). Because of this overwhelming support, Koizumi's cabinet lasted for 60 months, which was longer than any other recent cabinet ${ }^{6}$. Koizumi is thought to have been the LDP's most popular and influential prime minster, although there have been many political opponents. That is, Koizumi created many divisions in the LDP and in politics in Japan.

In the 2005 election, Koizumi had a fierce showdown with other LDP members in his fight to ensure that his signature economic policy - the privatization of the postal service-was the key election issue ${ }^{7}$. The policy was vehemently opposed by not only members of the opposition party, but also by many LDP members ${ }^{8}$. Koizumi led the LDP to win a landslide victory, proving that his controversial privatization policy was strongly supported by voters ${ }^{9}$. Consequently, various members of the non-government party and Koizumi's LDP opponents lost their seats ${ }^{10}$. After the election, they were expelled from the LDP because of their

\footnotetext{
${ }^{5}$ The LDP should not be confused with the now-defunct Liberal Party, which merged with the main opposition party, the Democratic Party of Japan, in November 2003.

${ }^{6}$ According to opinion polls, public support for Koizumi peaked at $85 \%$, the highest rating for a prime minister since 1989 (Yamamura and Sabatini, 2014).

${ }^{7}$ Apart from protecting the special interest group formed by local postmasters and postal workers, there were various reasons why that some politicians fiercely opposed postal privatization (Imai, 2009), including fundamental ideologies on the size and role of government and factional affiliations within the LDP.

${ }^{8}$ The bill to privatize the postal service was rejected in the House of Councilors in August 2005. The rebel LDP members essentially prevented the policy of postal privatization from being realized. Consequently, Koizumi dissolved the House of Representatives (Shugi-in) and called for a general election to seek the public's opinion on the bill.

${ }^{9}$ The results of the election, however, were unlikely to have influenced the happiness levels of voters (Tsutsui et al., 2010).

${ }^{10}$ In each constituency of the Shugi-in, only one candidate can be elected. For the purpose of avoiding internal conflicts, each party usually nominates a candidate for a constituency. However, in the 2005 election, Koizumi broke this rule and recruited "assassin" candidates to stand against those LDP members (representing some constituencies) who did not endorse the postal privatization bill.
} 
opposition to the LDP postal privatization.

Shinzo Abe became secretary-general of the LDP in September 2003 and thus played an important role in the Koizumi cabinet. Upon the expiration of Koizumi's term of office in September of 2006, Abe announced his intent to run for LDP president. He was successful and came to power establishing the first Abe cabinet as Koizumi's successor. However, Abe did not follow the policy of the former cabinet and gradually returned to traditional LDP policy. On the establishment of the first Abe cabinet, the former expelled LDP members submitted a petition and special covenant to the LDP. In November 2006, the Abe cabinet readmitted them to the LDP. As a result, the rate of support for the LDP declined. In the House of Councilors election of July of 2007, the LDP was defeated ${ }^{11}$. Thus, the first Abe cabinet came to an end in September of 2007, just one year after Abe came to power. The postal rebels' return to the LDP disappointed the supporters of the Koizumi cabinet and the decision was regarded the main reason for the decline in LDP support. To better understand the above political situation, let us briefly introduce the political and economic background of Japan's post-World War II period.

One of the key features of the Japanese electoral system should be discussed to better understand the long-term dominance of the LDP. In an election, candidates rely heavily upon their jiban, a strongly supportive and influential regional electoral power base (Miyake, 1989). The interests and perceived benefits of local voters are considered key in providing strong support for the LDP.

Prior to the emergence of the Koizumi cabinet, the LDP was considered a conglomeration of competitive factions (habatsu), engaged in bitter infighting (Cox and Rosenbluth, 1993). Habatsu play a fundamental role in every area of LDP political activity such as candidate nominations and the allocation of party and government posts (Köllner, 2006). Because of the smaller population density in rural areas and higher rate of agricultural workers, farmers formed agricultural cooperatives - essentially special interest groups - to protect and pursue their interests. Under an electoral system with geography-based constituencies, workers in the agricultural sector can have an important effect on election results even if the number of agricultural workers is smaller than those of other sectors. Therefore, politicians have an incentive to give some attention to the agricultural sector to increase their chances of re-election ${ }^{12}$. In Japan, politicians have been criticized for increasing expenditure on public infrastructure to attract the support of the construction industry (Yamamura and Kondoh, 2013).

\footnotetext{
11 In addition, a huge record-keeping blunder by the Social Insurance Agency and the Ministry of Health, Labour and Welfare is also considered a reason for the decline in support for the LDP.

12 Political parties attempt to direct budgetary resources into constituencies to maintain their electoral position (Kawaura, 2003; Meyer and Naka, 1998, 1999).
} 
For instance, some argue that public infrastructure has been excessively developed in rural areas, reducing economic efficiency. This is thought to be the reason why "larger amounts are spent on public works than in other countries, controlling for size and population" (Doi and Ihori 2009, p. 181). For example, Japan's public postal service was well established in low-population density areas even though it was inefficient from an economic viewpoint. However, the number of possible votes from the postal service sector was sufficiently large and therefore LDP politicians relied heavily upon these in the election. Thus, the LDP placed significant importance on protecting the agricultural sector and postal service for the sake of rural populations. LDP members of the Diet also formed committees called "policy tribes" (zoku-giin), which played critical roles in providing support in electoral campaigns ${ }^{13}$. The strong electoral support from these groups enabled the LDP to maintain a one-party cabinet in the post-World War II period.

In addition to the LDP, parties such as the Socialist Party relied heavily on the votes gathered from the labor unions; these parties pursued labor rights and the improvement of labor conditions. Hence, such parties were strongly supported by the labor union, considered a special interest group. The labor union is not limited to a particular area or industry. That is, politicians belonging to the Socialist Party did not rely upon a supportive network limited to rural areas and therefore had no incentive to care for any particular local industry. Thus, these parties aimed to redistribute income from the capitalist class to the labor class. The LDP and other parties shared a similar view in that they placed greater importance on income redistribution than the improvement of economic efficiency through the market. That is, before the Koizumi cabinet was established, the politically conservative LDP and other politically progressive parties shared a similar anti-market view, despite their obviously different political views. This might reflect the fact that Japanese are less likely to rely on the market mechanism than other developed countries (Ohtake, 2010).

Koizumi proposed an intensive program of neoliberal reforms ${ }^{14}$. Koizumi's policy had the objective of revitalizing the Japanese economy. In addition, his political message aimed to disconnect the ties among politicians, bureaucrats, and protected industries. Koizumi also believed that prices, profits, and employment levels should be governed by market forces rather than by a bargaining process between the political establishment and business organizations. LDP supporters were roughly divided into two groups: supporters who expected to benefit from

\footnotetext{
${ }^{13}$ The relationships among politicians, bureaucrats, and private companies are sometimes described as an "iron triangle" (Sakakibara, 2003).

${ }^{14}$ The reforms included the deregulation of industries (especially "protected" ones), the reduction of government size and public spending, and the privatization of public corporations.
} 
the redistribution policy under a traditional LDP and supporters who expected to benefit under the reform proposed by the Koizumi cabinet.

\section{Data and Hypothesis}

\subsection{Data}

With the aim of analyzing the relation between political factors and happiness, interview surveys were conducted every month throughout Japan for 32 months, from August 2005 to March 2008. During these 32 months, the LDP was the governing party and three prime ministers governed Japan ${ }^{15}$ : the Koizumi cabinet held power at the start of the interview period, from August 2005 to September $2006^{16}$, and the first Abe cabinet sat from September 2006 to September 2007, lasting only one year. Of Japan's various cabinets, the Koizumi cabinet represents the longest running government, in power since April 2001 for five and a half years. However, in the data, respondents were only asked to report their income level for a 19-month period from August 2005 to January 2007. Income level is the key variable in this analysis and so the sample used for estimation in this paper was limited to this period. The collection of data is based on the random sampling method and respondents are male and female adults aged over 20 years ${ }^{17}$. In each month, the questionnaire asked more than 1,000 respondents about their happiness, favored political parties, and their attributes, such as sex, age, school career, occupation, residence location, city size, as well as his or her view on the state of business.

Questions concerning the key variables are detailed below. The question about happiness level asked: Please remember how you felt in this one week. To what degree were you feeling happy in the last week? On a scale of $0-10$, where " 10 " is "very happy" and " 0 " is "very unhappy," how do you rate your level of happiness in the last week?

Table 1 presents the definitions of the variables used in this paper, as well as their basic statistics such as mean values, standard deviation, and maximum and minimum values (there is a distinct difference between these two values) during the study period. Following previous research (Ferrer-i-Carbonell, 2005, Fischer and Torgler, 2013), relative income position is defined as the difference between a respondent's income and the income of the reference group. This paper takes a geographic approach to reference groups following earlier studies

\footnotetext{
15 These were Koizumi, Abe and Yasuo Fukuda.

16 The LDP has been in a coalition partnership with New Komeito since 1999. New Komeito changed its English name to Komeito in September 2014.

17 New respondents were selected every month and therefore the data are not panel data.
} 
(Blanchflower and Oswald, 2004, Luttmer, 2005, Graham and Felton, 2006). In this paper, the reference group is the median income in the prefecture where the respondent resided. A relatively high (low) income is the absolute value of the difference between the respondent's income and the median income of the reference group. A relatively high (low) income is 0 when the respondent's income is lower (higher) than the median income. Median annual income within a residential prefecture varies from 1.50 million yen to 5.50 million yen, indicating that the level of the median income in the prefecture with the highest income is approximately three times that in the prefecture with the lowest income. In contrast, the mean annual income within a residential prefecture varies from 2.40 million yen to 6.31 million yen. Therefore, the difference of the mean income between them is almost the same. Estimation results possibly depend on the reference income group within a residential prefecture. For a robustness check, we also used the relative income, which is calculated by using mean income as the reference and then conducting the estimation. Estimation results based on the alternative measure of relative income are similar to those obtained using the relative income based on median income. Therefore, the results using the alternative relative income are not exhibited in this paper ${ }^{18}$. The rate of supporters for the LDP was $23 \%$, which is far from being a majority. This conveys that floating votes play a critical role in election results.

Intuitively, high earners are less likely to prefer income redistribution through progressive tax. In other words, those who support the party to promote market liberalization are thought to be high earners. In contrast, low-income earners prefer a policy of income redistribution because they will enjoy the benefits of such policy. If this holds true, there is a difference of composition of income groups between LDP supporters and others. However, we see from Table 2 that the rate of low-income earners is almost same for LDP supports and others, although the rate of high-income earning LDP supporters is $3 \%$ higher than that of others. All in all, the composition of the income groups of LDP supporters does not differ from that of others. Therefore, the sample of LDP supporters is comparable with that of others.

\subsection{Hypotheses}

An individual's expectation of income mobility is thought to influence SWB (Alesina et al., 2004). Piketty (1995) built a number of theoretical models to indicate that expectations of upward and downward mobility play an important role in determining individual attitudes toward redistribution. Bénabou and Ok (2001) provided the "prospect of upward mobility" hypothesis, where people who expect to move up the income scale will not favor a distributive

18 The results of the alternative specification are available upon request from the corresponding author. 
policy even if they are currently poor; this hypothesis is empirically supported by prior studies (Alesina and La Ferrara, 2005; Rainer and Siedler, 2008). If these hold true, the happiness levels of relatively low-income earners is not lower than the median income group when they expect to move up the income ladder. Furthermore, the reason why low-income earners supported the Koizumi cabinet is assumed to be that they expected the policy to increase their income through the market mechanism. Hypothesis 1 is proposed below:

Hypothesis 1: The negative effect of relatively low income on the happiness levels of non-LDP supporters is stronger than for LDP supporters.

As mentioned in section 2, the LDP traditionally cared for rural areas because it was backed by various interest groups to pursue benefits for rural areas. The LDP enhanced market liberalization by following the economic aims of Prime Minister Koizumi during the Koizumi cabinet period. However, the first Abe cabinet returned to traditional LDP policy, revisiting the redistribution of funds from urban to rural areas. Thus, the low-income earners that supported the Abe cabinet were unlikely to expect their income to increase, leading them to be unhappy. Therefore, we provide Hypothesis 2:

Hypothesis 2: The difference between the relative income effect of LDP supporters and non-LDP supporters decreased when LDP supporters did not expect their income to increase under the first Abe cabinet.

\subsection{Method}

The aim of the present study is to examine the effect of relative income and income inequality on Japanese happiness levels. That is, to test the Hypotheses proposed above, the estimated function takes the following form:

Happiness $_{\text {ist }}=\alpha_{0}+\alpha_{1}$ Median income $_{\mathrm{s}}+\alpha_{2}$ MHigh income $_{\text {ist }}+\alpha_{3}$ MLow income $_{\text {ist }}+\alpha_{4}$ Age $_{\text {ist }}$ $+\alpha_{4}$ Age square ${ }_{i s t}+\alpha_{5}$ High school $_{\text {ist }}+\alpha_{6}$ University $_{\text {ist }}+\alpha_{7}$ Man $_{\text {ist }}+\alpha_{8}$ Stock price $_{t}+\alpha_{9}$ Subjective economy ${ }_{i s t}+\alpha_{10}$ Support $L D P_{i s t}+u_{i s t}$

where Happiness ist represents the dependent variable in individual $i$, prefecture $s$, and year $t$. For detailed definitions of the variables, refer to Table 1. The regression parameters are denoted by $\alpha$, and the error term is by $u$. In this model, we regard the self-reported happiness level of an 
individual $i$ as a function of the relative income position of that individual in prefecture $s$. Following the research of Ferrer-i-Carbonell (2005), Median income, MHigh income, and MLow income are included to separate the effect of relative income from that of absolute income. If a relatively high income is positively related to happiness levels, MHigh income will be positive. In contrast, if a relatively low income is negatively related to happiness levels, MLow income will be negative. To examine Hypothesis 1, the sample is divided into a LDP supporter group and a non-LDP supporter group for the estimations. Furthermore, to examine Hypothesis 2, LDP supporters and non-LDP supporters are divided into samples under the Koizumi cabinet period and the first Abe cabinet period. Various individual characteristics are incorporated as independent variables. Age and its square are included to control for an individual's age. High school and University are included as proxies for human capital. To capture the economic situation, Stock price (the stock price at the beginning of the month) and Subjective economy (subjective views about Japan's economy) are included. Macroeconomic expansion in Japan makes people expect that their individual income will increase and so improve their happiness. In addition, occupation dummies, scale of area of residence, and year dummies are included as control variables.

\section{Results}

\subsection{Preliminary Analysis}

Prior to discussing the results of the regression analysis, we first discuss the results of the simple statistical analysis. Using the data, Figure 1 shows an association between the average values of MHigh income and the average values of happiness in each prefecture. Furthermore, Figure 2 shows an association between the average values of MLow income and the average values of happiness in each prefecture. The positive and negative relationships are observed in Figures 1 and 2, respectively.

Table 3 presents the mean difference of happiness levels between LDP supporters and non-LDP supporters for high-income, median income and low-income groups. The happiness level of the high-income group is higher than that of the median income group. The happiness level of the median income group is higher than that of the low-income group. It is surprising to observe that the difference is not statistically significant for LDP supporters whereas the difference is statistically significant at the $1 \%$ level for non-LDP supporters. Furthermore, for non-LDP supporters, the difference between the median income and the low-income groups is 0.33 , which is larger by 0.09 points than that between the high-income and median income groups. The happiness level differs between income groups for non-LDP supporters but not for 
LDP supporters. From this comparison, we derive the argument that the current income level is strongly related to happiness levels for non-LDP supporters but not for LDP supporters. Turning to the comparison between LDP supporters and non-LDP supporters, in all income groups, the happiness level of LDP supporters is higher than for non-LDP supporters. Its difference is statistically significant, which is consistent with Tsutsui et al. (2014). It is also interesting to observe that the difference in happiness levels is 0.15 points for the high-income group, 0.29 points for the median income group, and 0.50 points for the low-income group. That is, the lower one's income level is, the larger the difference of happiness levels between LDP supporters and non-LDP supporters. This is consistent with Hypothesis 1 .

Table 4 shows the rate of support for the LDP by area. During the Koizumi cabinet period, the rate is approximately $27 \%$ in urban and other areas. In contrast, during the first Abe cabinet period, the rate decreased to $24.1 \%$ in urban areas but increased to $29.4 \%$ in other areas. This is interpreted to reflect the change in policy. Therefore, compared with the period of the Koizumi cabinet, low-income LDP supporters during the first Abe period were likely to prefer income redistribution and were unhappy. This is in line with Hypothesis 2.

\subsection{Regression Analysis}

Tables 5 and 6 report the estimates obtained from the OLS model. The dependent variable discretely ranges from 0 to 10 and is therefore ordinal. In this case, the ordered probit model is preferable. The variable's coefficients cannot be interpreted as marginal effects and only suggest whether the variable has a positive (negative) effect. "Without a fair amount of extra calculation, it is quite unclear how the coefficients in the ordered probit model should be interpreted" (Greene 2008, 833). Hence, for convenience of interpretation, an OLS model is used in this study. The signs of the coefficients and their statistical significance based on the OLS model are the same as those using the ordered probit model; the results of the ordered probit model are not reported ${ }^{19}$.

We begin by discussing the results in Table 5 . Results based on the full sample are shown in column (1), while results based on the sample of LDP supporters and that of non-LDP supporters are in columns (2) and (3), respectively. We see from the column (1) that the coefficient of MHigh income is positive whereas that of MLow income is negative. Furthermore, they are statistically significant at the $1 \%$ level, which is consistent with Figures 1 and 2 . These results reveal that people with an income level above (below) the median income of the

19 Results using the ordered probit model are available upon request from the corresponding author. 
residential prefecture are more (less) likely to be happy than median income earners. Even after dividing the sample into two groups, the signs of MHigh income and MLow income do not change. MHigh income continues to be statistically significant at the $1 \%$ level regardless of respondents' political views. However, MLow income is statistically significant only for non-LDP supporters. This implies the following: people with an income level below the median income of the residential prefecture do not feel unhappier than median income earners if they support the LDP. Thus, the results in Table 5 strongly support Hypothesis 1. Furthermore, the coefficient of MHigh income is approximately 0.06 in columns (1) and (3) and 0.05 in column (2). Thus, the effect of a relatively high income does not change according to people's political views. The value of the coefficient of MHigh income in column (3) means that an increase of 1 million yen from the median income results in an increase in happiness by 0.06 points on the 10-point scale for non-LDP supporters. The coefficient of MLow income is approximately -0.10 in column (1) and -0.12 in column (3). The results in column (3) mean that a 1-million yen decrease from the median income results in a decrease in happiness level by 0.12 points on the 10-point scale for non-LDP supporters. Considering the results for both MHigh income and MLow income, we can argue that the effect of a relatively low income on happiness level is approximately two times larger than that of a relatively high income. Therefore, the effect of relative income position between poorer and richer individuals is asymmetric. In contrast to our findings, Duesenberry (1949, Chap. 2) asserted that that poorer people become unhappy when learning that their income is below that of their reference group, whereas richer individuals do not become happy from knowing their income is above that of their reference group. Duesenberry (1949, Chap. 2) also argued that progressive income taxes are necessary for allocational efficiency. This might be because Duesenberry (1949) did not take into account expectations of upward income mobility. If people have such an expectation, inequality does not reduce the happiness of low-income earners (Alesina et al., 2004). Thus, a relatively low-income position is not negatively associated with one's happiness level.

With respect to the results of other control variables in Table 5, the coefficients of Age and Age squared are negative and positive, respectively. Furthermore, they are statistically significant in all columns. This indicates that the relationship between age and happiness is U-shaped, as often found in happiness literature (Clark and Oswald, 1996; Blanchflower and Oswald, 2004; Kuroki, 2011). The coefficients of High school and University are positive in all columns. High school and University are statistically significant at the $1 \%$ level in columns (1) and (3). In contrast, High school is not statistically significant at the 5\% level in column (2) although University is. The value of the coefficient of University is also 0.31 in column (2) and 
0.46 in column (3). This implies that the happiness levels of those who graduated from university is higher by $0.31(0.46)$ points than those who graduated from junior high school if they are LDP supporters (non-LDP supporters). All in all, the effect of education on happiness levels is larger for non-LDP supporters than LDP supporters. This shows that happiness levels are less likely to depend on education for LDP supporters. Education level is regarded as an initial condition and does not change. If this effect determines future income levels, low-educated people cannot improve their income level. However, the estimation results are interpreted to imply that low-educated LDP supporters expect their income to increase. This is in line with the fact that happiness levels are less inclined to depend on current relative income for LDP supporters. In our interpretation, the initial and current condition is less likely to influence happiness levels if people expect that the condition will improve in the future through the market mechanism. Concerning macroeconomic factors, Subjective economy is significant and positive in all columns, which is consistent with expectations. However, the sign of Stock price varies according to columns, and it is not statistically significant in any columns. The coefficient of $L D P$ is positive and statistically significant at the $1 \%$ level. Hence, LDP supporters were happier than non-LDP supporters, which is consistent with Tsutsui et al. (2014).

We now turn to Table 6 where the results of the key variables are reported, although other control variables are included as independent variables. Regarding the results based on the Koizumi cabinet period, the results are almost the same as those reported in Table 5. However, in the first Abe cabinet period, the impact of relative income has obviously changed. As is reported in column (4), the coefficients of MHigh income and MLow income are positive and negative, respectively, and are statistically significant at the $1 \%$ level. The absolute values of the coefficients are 0.05 and 0.14 for MHigh income and MLow income, respectively. Therefore, the degree of the effect of MLow income is approximately three times larger than that of MHigh income. The difference between them comes from an increase in the absolute effect of MLow income. We interpret this as suggesting that low-income earners are less likely to expect an increase in income and an improvement in economic conditions. It is striking to observe that the coefficient of MLow income is significant and negative not only for non-LDP supporters but also for LDP supporters. Furthermore, its absolute values are 0.16 for LDP supporters and 0.13 for non-LDP supporters. Hence, the effect of a relatively low income is slightly larger for LDP supporters. Overall, relative income effects are almost the same for LDP supporters and non-LDP supporters. This suggests that the difference of the effects of relative income between them disappeared in the first Abe cabinet period. These results are congruent to Hypothesis 2. What is more, whereas the effect of a relatively high-income position continues to be positive, 
that of a relatively low-income position becomes negative when the prime minister changed from Koizumi to Abe. In other words, the effect of the relative income position between the poor and rich during the first Abe period became more symmetric than that during the Koizumi period. Turning to the key control variable, Subjective economy, it continues to be significant and positive in all columns. As a whole, the absolute values of the coefficients of Subjective economy are smaller in the first Abe cabinet period than in the Koizumi cabinet period. One interpretation of this result is as follows: people were less inclined to expect that a macroeconomic boom would lead to an increase in individual income under the first Abe cabinet period because they did not consider the market to function well.

\section{Conclusion}

Japan's longstanding governing party, the LDP, is based on a conservative political spirit and has formed a significant conservative force. Furthermore, historically, it pursued a policy of redistribution from rich urban areas to poor rural regions to attract votes. For instance, the LDP adopted a policy to protect the agricultural sector to obtain support from agricultural organizations, essentially representing special interest groups. However, the situation drastically changed after Koizumi became prime minister in 2001, when he adopted a market-oriented policy. Cabinet's policy orientation changed again when Abe came to power and returned to a "traditional LDP" methodology. He was politically conservative but placed significant emphasis on a return to a redistribution policy. Such a change in Japan's political situation, we believe, affected the impact of relative income position on happiness levels.

Using individual data from August 2005 to January 2007 in Japan, this paper attempts to examine whether the effects of relative income and income inequality differ based on whether respondents support the LDP. Our key findings are outlined below. During the study period, a relatively high income is positively related to happiness regardless of the respondent's support for the LDP. A relatively low income is negatively related to happiness. Such a tendency is observed if respondents do not support the LDP; in contrast, it is not observed if respondents support the LDP. These results imply that differing expectations of an increase in income mobility via the market lead to differences in the effect of relative income on happiness levels. Furthermore, after splitting the sample into two periods, the Koizumi cabinet and the first Abe cabinet, the results based on the sample of LDP supporters differs between the periods. However, the results based on the sample of non-LDP supporters do not change. The relative income effect for LDP supporters becomes similar to that of non-LDP supporters under the first Abe 
period. These results can be interpreted as implying that low-income LDP supporters expected upward income mobility via the market under the Koizumi cabinet, but not under the first Abe cabinet. Thus, low-income earners supported the LDP because they held that expectation under the Koizumi cabinet. In contrast, they did not expect any improvement of income position under the first Abe cabinet.

It is unclear whether the orientation of economic policy changes an individual's expectation of upward income mobility because there is the possibility that the composition of cabinet supporters changed as a consequence of the change of policy. This theory could be examined using panel data covering different cabinets. Of course, there is also the possibly endogenous bias because the causality between happiness and relative income is ambiguous. To scrutinize the effect of relative income position on happiness, it is necessary to use instrumental variables to solve any endogenous bias. An experimental approach could also be useful in this regard. These issues remain to be addressed in future research. 


\section{References}

Alesina, A., De Tella, R. MacCulloch, R. 2004. Inequality and happiness: are Europeans and Americans different? Journal of Public Economics, 88, 2009-2042.

Alesina, A.,La Ferrara, E. 2005. Preferences for redistribution in the land of opportunities. Journal of Public Economics, 89, 897-931.

Bénabou, R., Ok, E. A. 2001. Social mobility and the demand for redistribution: The PAUM hypothesis. Quarterly Journal of Economics, 116 (2), 447-487.

Blanchflower, D. G., Oswald, A. 2004. Well-being over time in Britain and the USA. Journal of Public Economics, 88, 1359-1386.

Clark, A., Oswald, A. 1996. Satisfaction and comparison income. Journal of Public Economics, 61(3), 359-381.

Clark, A., Frijters, P., Shields, M.A. 2008. Relative income, happiness, and utility: An explanation for the Easterlin paradox and other puzzles. Journal of Economic Literature, 46(1), 95-144.

Cox, G. W., Rosenbluth, F. 1993. The electoral fortunes of legislative factions in Japan. American Political Science Review, 87 (3), 577-589.

Doi, T., Ihori, T. 2009. The Public Sector in Japan: Past Development and Future Prospects. Cheltenham: Edward Elgar.

Duesenberry, J.S., 1949. Income, Saving and the Theory of Consumer Behavior. Harvard University Press, Cambridge.

Ferrer-i-Carbonell, Ada, 2005. Income and well-being: an empirical analysis of the comparison income effect. Journal of Public Economics, 89(5-6), 997-1019.

Fischer, J.A.V., Torgler, B.2013. Do positional concerns destroy social capital: evidence from 26 countries. Economic Inquiry, 51(2), 1542-1562.

Frank, R.H., 1985. The demand for unobservable and other non-positional goods. American Economic Review, 75, 101-116.

Graham, C. and Felton, A. 2006. Inequality and happiness: Insights from Latin America. Journal of Economic Inequality, 4, 107-122.

Greene, W. 2008. Econometric Analysis (Sixth edition) Prentice Hall, New Jersey.

Hollander, H., 2001. On the validity of utility statements: standard theory versus Duesenberry's. Journal of Economic Behavior and Organization, 45, 227-249/

Imai, M. 2009. Ideologies, vested interest groups, and postal saving privatization in Japan. Public Choice, 138, 137-160. 
Katz, R. 2001. Koizumi is blowing it. International Economy, 15(5), 38-39, 51.

Kawaura, A. 2003. Public resource allocation and electoral systems in the U.S. and Japan. Public Choice, 115, 63-81.

Kinari, Y., Ohtake, F., Kimball, M., Morimoto, S., Tsutsui, Y. 2014. Happiness before and after an election: an analysis based on a daily survey around Japan's 2009 Election, mimeo.

Köllner, P. 2006. The liberal democratic party at 50: sources of dominance and changes in the Koizumi era. Social Science Japan Journal 9(2), 43-57.

Kuroki, M. 2011. Does social trust increase individual happiness in Japan? Japanese Economic Review, 62(4), 444-459.

Luttmer, P. E., 2005. Neighbors as negatives: Relative earnings and well-being. Quarterly Journal of Economics, 120 (3), 963-1002.

Meyer, S.A., Naka,S. 1998. Legislative influences in Japanese budgetary politics. Public Choice, 94, 267-288.

Meyer, S.A., Naka,S. 1999. The determinants of Japanese local-benefit seeking. Contemporary Economic Policy, 17, 87-96.

Miyake, I. 1989. Tohyo kodo (The Voting Behavior). Tokyo: Tokyo University Press.

Ohtake, F. 2010. Kyoso to Koheikan: Shijo Keizai no Honto no Meritto (Competition and Justice: Merit of Market Economy). Tokyo: Chuokoron-sha.

Piketty, T., 1995. Social mobility and redistributive politics. Quarterly Journal of Economics, $110,551-584$.

Tsutsui, Y., Yamane, S., Ohtake, F., 2014. Why are cabinet supporters happy? . Mimeo.

Oshio, T., Nozaki, K., Kobayashi, M. 2011. Relative income and happiness in Asia: evidence from nationwide surveys in China, Japan, and Korea. Social Indicators Research, 104(3), 351-367.

Rainer, H., S, T. 2008. Subjective income and employment expectations and preferences for redistribution. Economics Letters, 99, 449-453.

Sakakibara, E. 2003. Structural Reform in Japan: Breaking the Iron Triangle. Washington, D.C.: Brookings Institution Press.

Tsutsui, Y., Kimball, M., Ohtake, F. 2010. Koizumi carried the day: did the Japanese election results make people happy and unhappy? European Journal of Political Economy, $26(1), 12-24$.

Tsutsui, Y. and Ohtake, F. 2012. Asking about changes in happiness in a daily web survey and its implication for the Easterlin Paradox. Japanese Economic Review, 63(1), 38-56.

Yamamura, E., Kondoh, H. 2013. Government transparency and expenditure in the rent-seeking 
industry: the case of Japan for 1998-2004. Contemporary Economic Policy, 31(3), 635-647.

Yamamura, E. Sabatini, F. 2014. Superstars in politics: the role of the media in the rise and success of Junichiro Koizumi. Econometica Working Papers wp56, Econometica..

Yamamura, E., Tsutsui, Y., Yamane, C., Yamane, S., Powdthavee, N. 2014. Trust and happiness: comparative study before and after the Great East Japan Earthquake. Forthcoming in Social Indicators Research. 


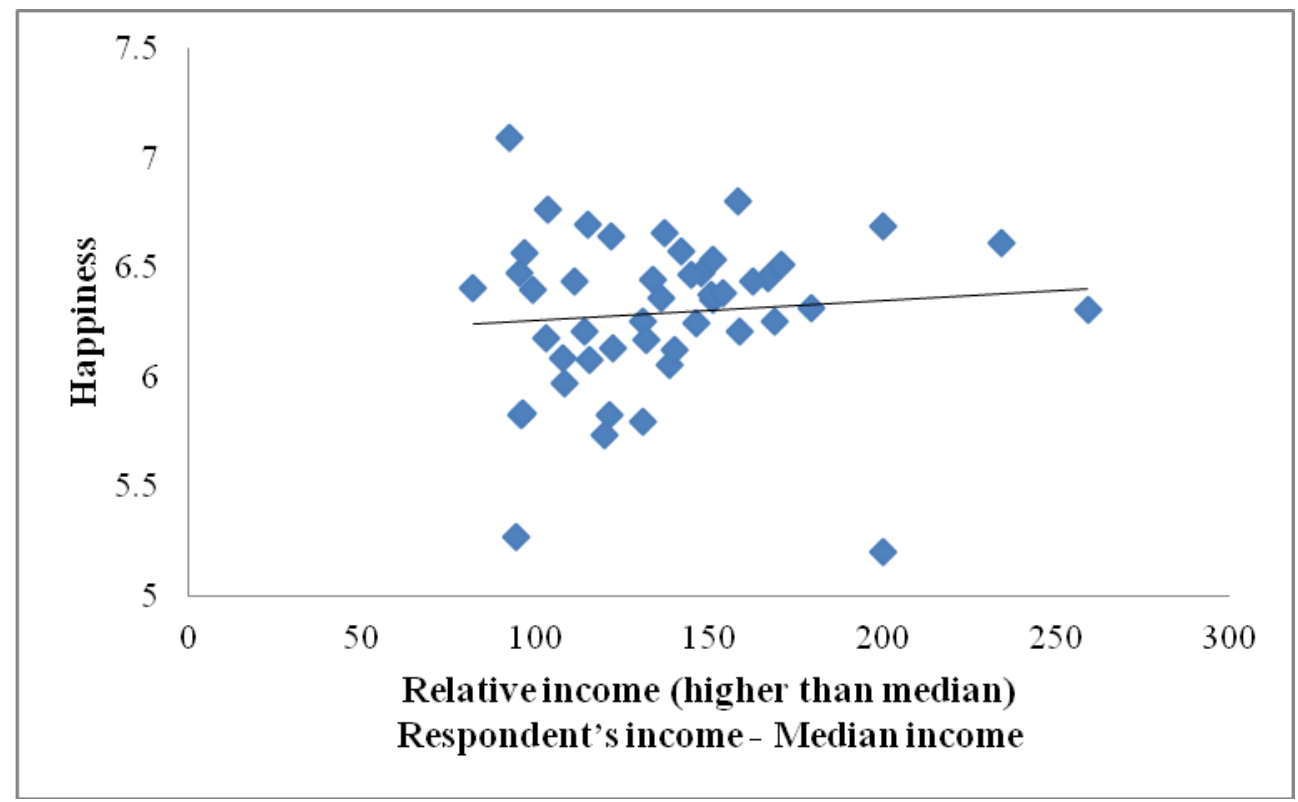

Figure 1. Association between happiness and relative higher income 


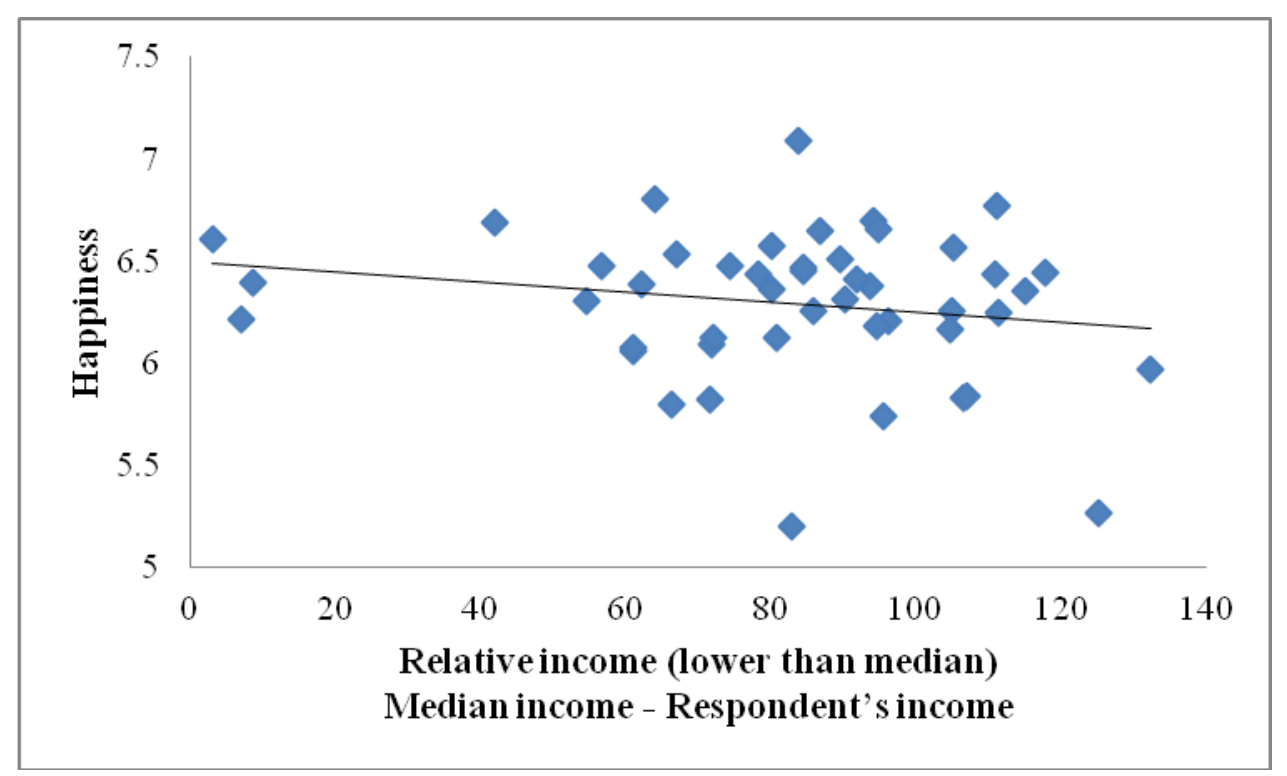

Figure 2. Association between happiness and relative lower income 
Table 1. Definitions of variables used for the estimation and its mean, standard deviation, maximum and minimum values

\begin{tabular}{|c|c|c|c|c|c|}
\hline & Definitions & Mean & $\begin{array}{l}\text { Standard } \\
\text { deviation }\end{array}$ & Max & Min \\
\hline Happiness & $\begin{array}{l}\text { The degree of happiness } \\
\text { Question: How would you rate your current level of happiness? } \\
0 \text { (very unhappy) to } 10 \text { (very happy) }\end{array}$ & 6.32 & 1.94 & 10 & 0 \\
\hline $\begin{array}{l}\text { Median } \\
\text { Income }\end{array}$ & Median annual income within prefecture (million yen) & 4.41 & 0.83 & 5.50 & 1.50 \\
\hline $\begin{array}{l}\text { MHigh } \\
\text { income }\end{array}$ & $\begin{array}{l}\text { Absolute value: respondent's annual income-median annual income } \\
\text { within prefecture (million yen) }\end{array}$ & 1.35 & 2.22 & 12.5 & 0 \\
\hline $\begin{array}{l}\text { MLow } \\
\text { income }\end{array}$ & $\begin{array}{l}\text { The value is } 0 \text { if median income is higher than respondent's income } \\
\text { Absolute value: respondent's annual income-median annual income } \\
\text { within prefecture (million yen) } \\
\text { The value is } 0 \text { if median income is lower than respondent's income }\end{array}$ & 0.88 & 1.23 & 4.50 & 0 \\
\hline Age & Ages & 51.4 & 16.6 & 99 & 20 \\
\hline Age square & Square of ages & ---- & ---- & ---- & \\
\hline Stock price & Stock price $(10,000$ yen $)$ & 1.587 & 0.15 & 1.81 & 1.19 \\
\hline Subjective & View of Japan's economy & 2.82 & 0.66 & 5 & 1 \\
\hline $\begin{array}{l}\text { Economy } \\
\text { Man }\end{array}$ & $\begin{array}{l}1 \text { (certainly bad) to } 5 \text { (certainly improved) } \\
1 \text { if respondent is male, otherwise } 0\end{array}$ & 0.47 & ----- & 1 & 0 \\
\hline High school & 1 if respondent graduated from high school, otherwise 0 & 0.51 & ---- & 1 & 0 \\
\hline University & $\begin{array}{l}1 \text { if respondent graduated from university or graduate school, } \\
\text { otherwise } 0\end{array}$ & 0.32 & ---- & 1 & 0 \\
\hline$L D P$ & 1 if respondent supports the LDP, otherwise 0. & 0.23 & ---- & 1 & 0 \\
\hline
\end{tabular}

Note: Gini coefficients are sourced from the Statistics Bureau (Ministry of Internal Affairs and Communications).

http://www.e-stat.go.jp/SG1/estat/List.do?bid=000000640081\&cycode=0. (accessed on August 27, 2014). Stock price obtained from monthly data from the Nihon Keizai Shimbun (Nikkei, a Japanese economic newspaper). http://indexes.nikkei.co.jp/nkave/archives/data. (accessed on August 23, 2014). 
Table 2. Composition of income level between LDP supporters and non-LDP supporters $(\%)$

\begin{tabular}{lcc}
\hline & LDP supporters & Non-LDP supporters \\
\hline $\begin{array}{l}\text { Higher than median } \\
\text { income }\end{array}$ & 44.3 & 41.7 \\
$\begin{array}{l}\text { Median income } \\
\begin{array}{l}\text { Lower than median } \\
\text { income }\end{array}\end{array}$ & 10.7 & 12.9 \\
\hline
\end{tabular}

Note: Median income in the prefecture where respondents live is used. 
Table 3. Mean difference test of happiness levels between LDP supporters and non-LDP supporters

\begin{tabular}{|c|c|c|c|c|}
\hline & $\begin{array}{l}\text { LDP } \\
\text { supporters } \\
\quad(1)\end{array}$ & $\begin{array}{l}\text { Non-LDP } \\
\text { supporters } \\
(2)\end{array}$ & $\begin{array}{l}\text { Difference } \\
\text { happiness level } \\
(2)-(1)\end{array}$ & t-values \\
\hline $\begin{array}{l}\text { Higher than median income } \\
\text { (I) }\end{array}$ & 6.64 & 6.48 & 0.15 & $2.56^{* *}$ \\
\hline $\begin{array}{l}\text { Median income } \\
\text { (II) }\end{array}$ & 6.53 & 6.24 & 0.29 & $2.25 * *$ \\
\hline $\begin{array}{l}\text { Lower than median income } \\
\text { (III) }\end{array}$ & 6.41 & 5.91 & 0.50 & $7.52 * * *$ \\
\hline $\begin{array}{l}\text { Difference of happiness level } \\
\text { (I)-(II) }\end{array}$ & 0.10 & 0.24 & & \\
\hline $\begin{array}{ll}\mathrm{t} \text {-values } \\
\text { (I) versus } & \text { (II) }\end{array}$ & 0.89 & $3.45 * * *$ & & \\
\hline $\begin{array}{l}\text { Difference of happiness level } \\
\text { (II)-(III) }\end{array}$ & 0.12 & 0.33 & & \\
\hline $\begin{array}{l}\text { t-values } \\
\text { (II) versus (III) }\end{array}$ & 0.99 & $4.34 * * *$ & & \\
\hline
\end{tabular}

Note: Median income in the prefecture where respondents live is used.

$*, * *$ and $* * *$ indicate significance at the $10 \%, 5 \%$ and $1 \%$ levels, respectively. 
Table 4. Comparison of the rate of LDP supporters between rural and urban areas (\%)

\begin{tabular}{lll}
\hline & Urban & Others \\
\hline $\begin{array}{l}\text { Koizumi cabinet } \\
\text { August 2005-August 2006 }\end{array}$ & 27.1 & 27.2 \\
$\begin{array}{l}\text { Abe cabinet } \\
\text { September 2006-January 2007 }\end{array}$ & 24.1 & 29.4 \\
\hline
\end{tabular}

Note: Urban areas are defined as the Tokyo metropolitan area and Osaka Prefecture. 
Table 5. Dependent variable is happiness level (OLS model)

\begin{tabular}{|c|c|c|c|}
\hline & $\begin{array}{l}(1) \\
\text { All }\end{array}$ & \begin{tabular}{l}
\multicolumn{1}{c}{$(2)$} \\
LDP \\
supporter
\end{tabular} & $\begin{array}{l}\text { (3) } \\
\text { Non-LDP } \\
\text { supporter }\end{array}$ \\
\hline $\begin{array}{l}\text { Median } \\
\text { income }\end{array}$ & $\begin{array}{l}-0.08 \\
(-0.99)\end{array}$ & $\begin{array}{l}-0.25 \\
(-1.13)\end{array}$ & $\begin{array}{l}-0.02 \\
(-0.23)\end{array}$ \\
\hline $\begin{array}{l}\text { MHigh } \\
\text { income }\end{array}$ & $\begin{array}{l}0.06^{* * * *} \\
(6.81)\end{array}$ & $\begin{array}{l}0.05^{* * * *} \\
(3.34)\end{array}$ & $\begin{array}{l}0.06 * * * \\
(5.89)\end{array}$ \\
\hline MLow income & $\begin{array}{l}-0.10 * * * \\
(-5.32)\end{array}$ & $\begin{array}{l}-0.06 \\
(-1.64)\end{array}$ & $\begin{array}{l}-0.12 * * * \\
(-5.39)\end{array}$ \\
\hline Age & $\begin{array}{l}-0.03 * * * \\
(-3.56)\end{array}$ & $\begin{array}{l}-0.03 * \\
(-1.93)\end{array}$ & $\begin{array}{l}-0.03 * * * \\
(-2.73)\end{array}$ \\
\hline Age square & $\begin{array}{l}0.0003 * * * \\
(3.46)\end{array}$ & $\begin{array}{l}0.0003 * * \\
(2.02)\end{array}$ & $\begin{array}{l}0.0003 * * \\
(2.57)\end{array}$ \\
\hline High school & $\begin{array}{l}0.23 * * * \\
(3.48)\end{array}$ & $\begin{array}{l}0.11 \\
(1.06)\end{array}$ & $\begin{array}{l}0.30 \text { *** } \\
(3.46)\end{array}$ \\
\hline University & $\begin{array}{l}0.40 * * * \\
(5.34)\end{array}$ & $\begin{array}{l}0.31 * * \\
(2.44)\end{array}$ & $\begin{array}{l}0.46^{* * * *} \\
(4.77)\end{array}$ \\
\hline Man & $\begin{array}{l}-0.38 * * * \\
(-7.89)\end{array}$ & $\begin{array}{l}-0.43^{* * *} * \\
(-4.81)\end{array}$ & $\begin{array}{l}-0.37 * * * \\
(-6.36)\end{array}$ \\
\hline Stock price & $\begin{array}{l}-0.02 \\
(-0.12)\end{array}$ & $\begin{array}{l}0.11 \\
(0.29)\end{array}$ & $\begin{array}{l}-0.14 \\
(-0.54)\end{array}$ \\
\hline $\begin{array}{l}\text { Subjective } \\
\text { Economy }\end{array}$ & $\begin{array}{l}0.28 * * * \\
(8.69)\end{array}$ & $\begin{array}{l}0.33 * * * \\
(5.84)\end{array}$ & $\begin{array}{l}0.26 * * * \\
(6.60)\end{array}$ \\
\hline$L D P$ & $\begin{array}{l}0.28 * * * \\
(6.60)\end{array}$ & & \\
\hline R-square & 0.07 & 0.09 & 0.07 \\
\hline Observations & 9552 & 2792 & 6760 \\
\hline
\end{tabular}

Note: Numbers in parentheses are t-values calculated using robust standard errors. * ** and $* * *$ indicate significance at the $10 \% 5 \%$ and $1 \%$ levels, respectively. Occupation dummies, scale of area of residence, year dummies and constants are included but the results are not reported. Coefficients of stock price are calculated based on the values of stock price in units of 10,000 yen. 
Table 6. Dependent variable is happiness level (OLS model): Sub-sample estimation

\begin{tabular}{|c|c|c|c|c|c|c|}
\hline & \multicolumn{3}{|c|}{ Koizumi cabinet } & \multicolumn{3}{|c|}{ First Abe cabinet } \\
\hline & (1) & $(2)$ & (3) & (4) & $(5)$ & (6) \\
\hline & All & LDP & Non-LDP & All & LDP & Non-LDP \\
\hline & & supporter & supporter & & supporter & supporter \\
\hline $\begin{array}{l}\text { Median } \\
\text { income }\end{array}$ & $\begin{array}{l}-0.17^{*} \\
(-1.67)\end{array}$ & $\begin{array}{l}-0.30 \\
(-1.19)\end{array}$ & $\begin{array}{l}-0.12 \\
(-1.03)\end{array}$ & $\begin{array}{l}0.21 \\
(1.33)\end{array}$ & $\begin{array}{l}-0.15 \\
(-0.36)\end{array}$ & $\begin{array}{l}0.32 * \\
(1.79)\end{array}$ \\
\hline MHigh income & $\begin{array}{l}0.06 * * * \\
(5.68)\end{array}$ & $\begin{array}{l}0.05 * * * \\
(2.97)\end{array}$ & $\begin{array}{l}0.06 * * * \\
(4.87)\end{array}$ & $\begin{array}{l}0.05 * * * \\
(3.40)\end{array}$ & $\begin{array}{l}0.06 * \\
(1.95)\end{array}$ & $\begin{array}{l}0.06 * * * \\
(2.86)\end{array}$ \\
\hline MLow income & $\begin{array}{l}-0.09 * * * \\
(-4.14)\end{array}$ & $\begin{array}{l}-0.02 \\
(-0.54)\end{array}$ & $\begin{array}{l}-0.12 * * \\
(-2.03)\end{array}$ & $\begin{array}{l}-0.14 * * * \\
(-3.46)\end{array}$ & $\begin{array}{l}-0.16 * * \\
(-2.16)\end{array}$ & $\begin{array}{l}-0.13 * * * \\
(-2.80)\end{array}$ \\
\hline Stock price & $\begin{array}{l}-0.07 \\
(-0.34)\end{array}$ & $\begin{array}{l}0.07 \\
(0.18)\end{array}$ & $\begin{array}{l}-0.21 \\
(-0.76)\end{array}$ & $\begin{array}{l}3.54 \\
(0.47)\end{array}$ & $\begin{array}{l}13.8 \\
(0.97)\end{array}$ & $\begin{array}{l}1.53 \\
(0.17)\end{array}$ \\
\hline $\begin{array}{l}\text { Subjective } \\
\text { Economy }\end{array}$ & $\begin{array}{l}0.29 * * * \\
(7.86)\end{array}$ & $\begin{array}{l}0.35 * * * \\
(5.37)\end{array}$ & $\begin{array}{l}0.27 * * * \\
(5.93)\end{array}$ & $\begin{array}{l}0.24 * * * \\
(3.63)\end{array}$ & $\begin{array}{l}0.29 * * \\
(2.30)\end{array}$ & $\begin{array}{l}0.22 * * * \\
(2.77)\end{array}$ \\
\hline$L D P$ & $\begin{array}{l}0.28 * * * \\
(5.68)\end{array}$ & & & $\begin{array}{l}0.28 * * * \\
(3.30)\end{array}$ & & \\
\hline R-square & 0.08 & 0.10 & 0.07 & 0.08 & 0.15 & 0.09 \\
\hline Observations & 7116 & 2093 & 5023 & 2436 & 699 & 1737 \\
\hline
\end{tabular}

Note: Sample is divided into the Koizumi cabinet (August 2005-August 2006) and the first Abe cabinet (September 2006-January 2007). Numbers in parentheses are $\mathrm{t}$-values calculated using robust standard errors. *, ** and *** indicate significance at the $10 \%$ $5 \%$ and $1 \%$ levels, respectively. All control variables used in Table 5 are included but the results are not reported. 